\title{
Seasonal Variations of Water Uptake Patterns by Deep-Rooted Grass in the Lake Qinghai Watershed
}

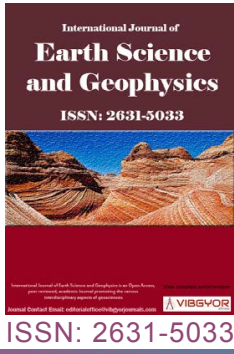

\section{Jing $\mathrm{Li}^{1^{*}}$, Shenguo $\mathrm{Mo}^{1}$, Huawu $\mathrm{Wu}^{2}$ and Zhicheng $\mathrm{Bao}^{3}$}

${ }^{1}$ Tourism School, Jiujiang College, China

${ }^{2}$ Nanjing Institute of Geography and Limnology, Chinese Academy of Sciences, China

${ }^{3}$ Jiangxi Province Earthquake Bureau, Nanchang, China

\begin{abstract}
Water availability controls steppe primary productivity, and it varies temporally and spatially in semi-arid and arid environments. In this study, we examined isotopic signatures of tissue water growing in three habitats and from environmental water sources. The results indicated that Achnatherum splendens water utilization varied both temporally and in response to changes in soil water conditions. $A$. splendens water uptake patterns were similar across the three habitats, with proportionally greater dependence on upper $20 \mathrm{~cm}$ soil water during wet periods. However, as soil moisture became increasingly depleted, $A$. splendens water uptake shifted from $0-20 \mathrm{~cm}$ to $40-60 \mathrm{~cm}$ soil layers. This plasticity of water use in A. splendens was significantly more responsive to changes in soil water conditions at the rainout treatment site than at the other two sites. In additional, these results suggest $A$. splendens does not use deep groundwater as the main water source in the three habitats assessed here and do not acquire unreliable stream water at the streamside site. Overall, $A$. splendens has the ability to adjust the soil water sources and thus adapts to spatiotemporal changes of soil water conditions. These results provide useful information for understanding ecosystem responses to water availability in arid/semiarid zones.
\end{abstract}

\section{Keywords}

Stable isotopes, Soil water content, Plasticity, Iso-Source mixing model, Climate change

\section{Introduction}

Water availability is an important factor influencing numerous measures of plant growth and ecosystem structure including species richness, productivity, and community stability [1,2]. Future climate predictions of changes in precipitation patterns and intense drought during the growing season result in reduced soil water availability and ecosystem functioning, and particularly in the arid and semiarid region [1-3] and will increase water stress for plants.

Increased concerns have been focused on the effects of summer precipitation events on water-use strategy of perennial plants in arid/semiarid ecosystems [4-6]. Variation in depth of water extraction by plant functions a trade-off between the activity

*Corresponding author: Dr. Jing Li, Tourism School, Jiujiang College, Jiujiang, 332005, China

Accepted: June 08, 2019; Published: June 10, 2019

Copyright: (C) $2019 \mathrm{Li} \mathrm{J}$, et al. This is an open-access article distributed under the terms of the Creative Commons Attribution License, which permits unrestricted use, distribution, and reproduction in any medium, provided the original author and source are credited.

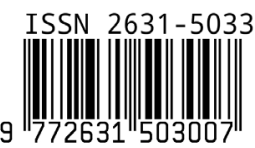

Li et al. Int J Earth Sci Geophys 2019, 5:025 
of surface and deep roots. Several studies showed that the water-uptake pattern of deep-rooted trees or shrub and different plant function types, showing that these plant had high degree of plasticity to absorb water in response to summer precipitation to maintain growth, for example, F. tinctoria in tropical forest [7], Juniperus ashei on Edwards Plateau [4] and dry forests tree species growing on shallow karst soils [8]. In brief, these plants with flexible water-use strategies can well buffer the effects of change in water-source availability to adapt the (seasonally) dry environment. The differential use of water source can impact ecosystem water balance $[9,10]$, vegetation response to climate change and even distribution pattern [11]. However, fewer researches have examined the water-use patterns of deep-rooted grass and it is still unclear. Here, we set a deep-rooted grass Achnatherum splendens, a drought-tolerant grass with dense fibrous roots, as an example to investigate how its water-uptake patterns response to water availability in the cold or high altitude regions.

A. splendens steppe is an important ecosystem in Lake Qinghai watershed, occupying about one third of the whole watershed $\left(29,660 \mathrm{~km}^{2}\right)$ around the shoreline of Lake Qinghai. Its patchy distribution provides favorable microenvironments for other associated species and plays vital roles in environmental protection and conversation of water and soil in this region $[12,13]$. Lake Qinghai watershed has experienced many ecological and environmental problems, such as lake-level decline and degradation of $A$. splendens community. It is still unclear whether degradation of $A$. splendens community is due to the effects of climate change on water-use patterns of $A$. splendens or to human activities in this region. As a result, knowledge of water-utilization pattern according to water availability to understand the degradation is an important research question.

In order to investigate the water-use patterns of $A$. splendens, we combined isotope analysis with soil water content (SWC) at three different habitats during the growing seasons: Streamside, non-streamside, and rainout treatment (covered with a plastic shelter). Our objectives of this study were to (1) Determine the depth of soil water uptake by $A$. splendens across different seasons, and (2) Examine how soil water moisture dynamics and recent precipitation affect $A$. splendens water uptake patterns during the growing seasons.

\section{Materials and Methods}

\section{Study site description}

The study site $\left(100.19^{\circ} \mathrm{E}, 37.24^{\circ} \mathrm{N}, 3217\right.$ m.a.s.l. $)$ was located in the lower reach of Shaliu River Basin, north of Lake Qinghai. The observation site was approximately $1 \mathrm{~km}$ away from Sanjiao $C$ town (Figure 1a). The region is situated in a semi-arid, cold, high-altitude climate zone dominated by the East Asian monsoon during the growing season. The mean annual temperature of the drainage basin is $0.1{ }^{\circ} \mathrm{C}$, and the mean annual precipitation is approximately $400 \mathrm{~mm}$, with more than $65 \%$ of the precipitation falling between June and September. The mean annual evaporation is approximately $1,300 \mathrm{~mm}$, with over $65 \%$ occurring in the warmer summer season $[12,14]$. The study site is used as a winter and spring grazing pasture for yak and sheep between December and June, and livestock fences were erected there in 1981. Vegetation cover was composed of mixed grasses dominated by Stipa breviflora, Agropyron cristatum, Carex ivanova, Heteropappus altaicus, and Koeleria cristata enclosing $A$. splendens tussocks (Figure 1b). The soil was mainly composed of chestnut soil, with high levels of spatial heterogeneity. Soil depth was about $0.6 \mathrm{~m}-1.0 \mathrm{~m}$, with a soil clay content of $34.8 \%-45.3 \%$, soil bulk density of $1.21 \mathrm{gm}^{-3}$, and a shallow soil field water capacity of $29.7 \%-32 \%$, below this soil depth with different particles of gravel [15].

In order to evaluate $A$. splendens water uptake in response to changes of water conditions, we designed three experimental plots within the fenced area, including streamside, rainout treatment, and non-streamside conditions. Streamside and non-streamside plots were approximately $1 \mathrm{~m}$ and $1.5 \mathrm{~km}$, respectively, away from the stream, and both were subject to rainfall input. Thus, these two plots differentiated between $A$. splendens using stream water or rainfall as the main water source.

The rainout treatment plot was designed in order to typically discern the plasticity of water uptake in $A$. splendens under a prolonged drought microenvironment. It consisted of a rainfall exclusion system (shelter with $2.4 \mathrm{~m}$ length $\times 3.0 \mathrm{~m}$ width $\times$ $0.9 \mathrm{~m}$ height) built next to the non-streamside plot; To avoid lateral infiltration of soil water, a trench $0.4 \mathrm{~m}$ width $\times 0.6 \mathrm{~m}$ depth was excavated around 


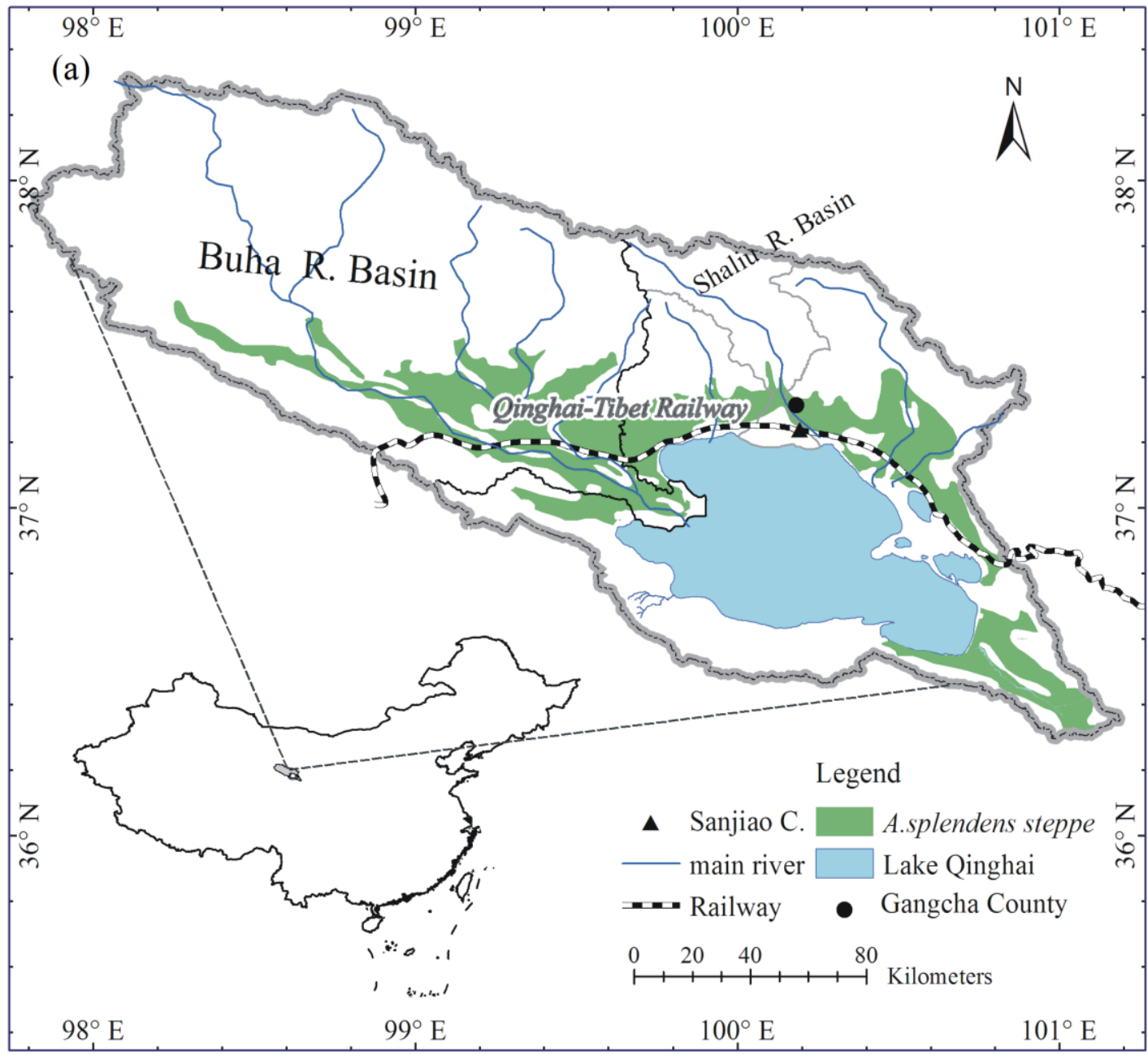

(b)

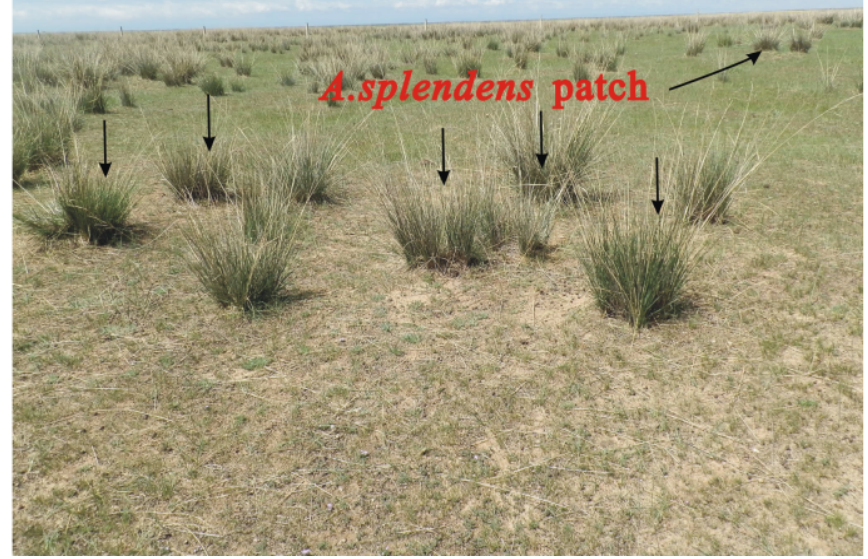

Figure 1: Geographic location of the study region and the Lake Qinghai catchment on the Qinghai-Tibet Plateau. Green area represents the distribution of typical $A$. splendens steppe around the Lake Qinghai catchment (a) The spatial landscape distribution pattern for $A$. splendens was showed in the lower panel (b).

the rainout treatment plot and lined with transparent plastic film. The aboveground sides of this plot were open on all sides for ventilation, and the roof was made of a transparent plastic film positioned above six $A$. splendens tussocks to prevent natural rainfall. The rainfall exclusion system stayed on the study site for a one month observation period beginning on July 5 , because the $A$. splendens community was not subject to grazing disturbance during this period. This plot was subjected to two watering events in order to test the plasticity of water uptake in response to water conditions: $200 \mathrm{~L}$ ground- 
water was added on July 21 , and $250 \mathrm{~L}$ groundwater was added on July 31 , where groundwater was collected from the herdsman well.

\section{Samplings of plant, soil, precipitation and groundwater}

We collected the white culms (non-photosynthetic tissue) of $A$. splendens $1-2 \mathrm{~cm}$ below the soil surface at three habitats (streamside, rainout treatment, and non-streamside) during a single growing season (streamside: Jun. 14, Jul. 5, Jul. 18, Aug. 10, Aug. 24, Sep. 9; Non-streamside: Jun. 10, Jul. 5, Jul. 18, Aug. 9, Aug. 24, Sep. 9; Rainout treatment: Jul. 5, Jul. 8, Jul. 12, Jul. 18, Jul. 23, Jul. 27, Aug. 1). All plant samples were collected from plants with green transpiring leaves. The isotopic values of water from culms and bulbs of grasses are known to represent sources of water uptake by plants from different soil profiles [16]. We sampled three replicates of $A$. splendens at each of three habitats, with one to three replicates analyzed due to technical issues with some samples during water extraction. All plant tissues were immediately placed in airglass, sealed with parafilm, and taken to the laboratory in a portable icebox with freeze packs, where they were stored at $-4{ }^{\circ} \mathrm{C}$ until vacuum extraction.

Since the roots of $A$. splendens are mainly distributed in the upper $0.6 \mathrm{~m}$ soil layer [17], soil samples were collected at different depths by a $1.5 \mathrm{~m}$ manual auger ( $5 \mathrm{~cm}$ internal diameter) at three habitats concurrent with plant tissue sampling. Due to the heterogeneity of soil depth, soil sampling depths were different among three habitats. For the streamside site, soil samples were collected at six depths: $0-10 \mathrm{~cm}, 10-20 \mathrm{~cm}, 20-30 \mathrm{~cm}, 30-40 \mathrm{~cm}$, $40-60 \mathrm{~cm}$ and $60-80 \mathrm{~cm}$. At rainout treatment and non-streamside sites, five soil depths were collected: $0-10 \mathrm{~cm}, 10-20 \mathrm{~cm}, 20-30 \mathrm{~cm}, 30-40 \mathrm{~cm}$ and $40-$ $60 \mathrm{~cm}$. At each habitat site, three soil cores were collected; Adjacent sampled A. splendens plants, then soil cores were divided into two groups. One group was put into a screw-cap glass vial covered with Parafilm for subsequent cryogenic vacuum distillation. These soil samples were taken to the laboratory in a portable icebox with freeze packs, where they were stored at $-4{ }^{\circ} \mathrm{C}$ to prevent the evaporation of soil water. The other was placed in plastic bags, carefully sealed to measure gravimetric soil water content (SWC, \%) and subsequently oven-dried to constant weights at $105{ }^{\circ} \mathrm{C}$ for 24 hours until constant weight.

Fifty-two event-based precipitation samples were collected during the period from April to September 2013 at the Sanjiaocheng Sheep Breeding Farm, which is about $10 \mathrm{~km}$ away from Gangcha County (Figure 1a). The rainwater collector, was constructed using a $10 \mathrm{~cm}$ diameter funnel connected to a glass bottle and contained a ping-pong ball to reduce evaporation. Each sample was collected as soon as the precipitation was estimated to have finished reducing evaporation, and meanwhile we recorded precipitation volume, air temperature, and precipitation patterns using an automatic weather station at the non-streamside site. Any snow samples were collected and sealed with a plastic bag, then held at room temperature until completely melted. All precipitation samples were transferred into clean polyethylene bottles $(30 \mathrm{ml}$ ) sealed with Parafilm. In our analysis, groundwater was assumed to be a potential water source available to $A$. splendens, because the water table did not exceed $3 \mathrm{~m}$ when we collected weekly groundwater samples from a herdsman's well from May to September. The well was approximately $0.5 \mathrm{~km}$ away from the non-streamside and approximately $1.5 \mathrm{~km}$ away from the streamside site. The groundwater table was no less than $2.5 \mathrm{~m}$ survey from a herdsman well by meter rule. Stream water was also collected in concurrence with sampling at the streamside habitat.

\section{Isotopic analysis}

Water was extracted from soil and plant tissues using a cryogenic vacuum distillation method $[18,19]$. Stable isotopic compositions $\left(\delta^{18} \mathrm{O}\right.$ and $\left.\delta D\right)$ of all sample extracts were analyzed at the State Key Laboratory of Earth Surface Process and Resource Ecology, Beijing Normal University, using an LGR DLT-100 (model: 908-0008) Laser Adsorption Spectroscope (Los Gatos Research, Inc., Mountain View, CA, USA). The isotope composition data were expressed conventionally as $\delta$ values, which represent deviations in per mil (\%o) from V-SMOW (Vienna Standard Mean Ocean Water) standards for oxygen-18 and deuterium, such that

$$
\delta_{\text {sample }}=1000 \times\left[\left(R_{\text {sample }} / R_{\text {vSMow }}\right)-1\right] \text {, }
$$

Where $\mathrm{R}$ is the ratio of ${ }^{18} \mathrm{O} /{ }^{16} \mathrm{O}$ or $\mathrm{D} / \mathrm{H}$, in the sample or in the standard. The measurement precision was $\pm 1.2 \%$ o for $\delta \mathrm{D}$ and $\pm 0.3 \%$ o for $\delta^{18} \mathrm{O}$. Isotopic data from extracted plant water were first checked for spectral interference using 
Spectral Contamination Identifier (LWIA-SCI) postprocessing software (Los Gatos Research, Inc.) because stable isotopic ratios of plant water can be easily affected by organic contamination, such as methanol and ethanol, which lead to spectral interference and produced erroneous isotopic values $[20,21]$. The calibration to account for organic contamination was described by $\mathrm{Wu}$, et al. [21].

\section{Data analysis}

In this study, two methods were used to identify water uptake of $A$. splendens. One was a direct isotopic inference approach to determine where soil profile water was actively absorbed by plants. In this approach, isotopic compositions of plant tissue water and potential water pools were compared to evaluate the most likely sources of water uptake. This approach presumes that the only possible water sources are soil water and plant up- take water from a single depth zone [22]. Thus, this method can only be applied to soil profiles where the isotopic gradient is not asymptotic or irregular. However, contributions to plant water uptake from different water sources may be misinterpreted by the direct inference approach. Hence, we also evaluated the relative contribution of each potential source to the plant using the IsoSource mixing model, which is based on multi-source mass balance [23]. Due to the similar variations between $\delta D$ and $\delta^{18} \mathrm{O}$ in soil and plant tissue water, we selected $\delta \mathrm{D}$ to evaluate plant water-use pattern. The fractional increment was set at $1 \%$, and the uncertainty level was set at 0.05 in this study, similar to previous studies $[24,25]$. Sensitivity analysis performed with different fractional increments $(0.5,2 \%)$ and different uncertainty levels $(0.1,0.3$, and 0.4$)$ showed no significant differences from the initial model.

Statistical analyses were performed in SPSS Version 13.0 (SPSS Inc., Chicago, USA). A general lin-
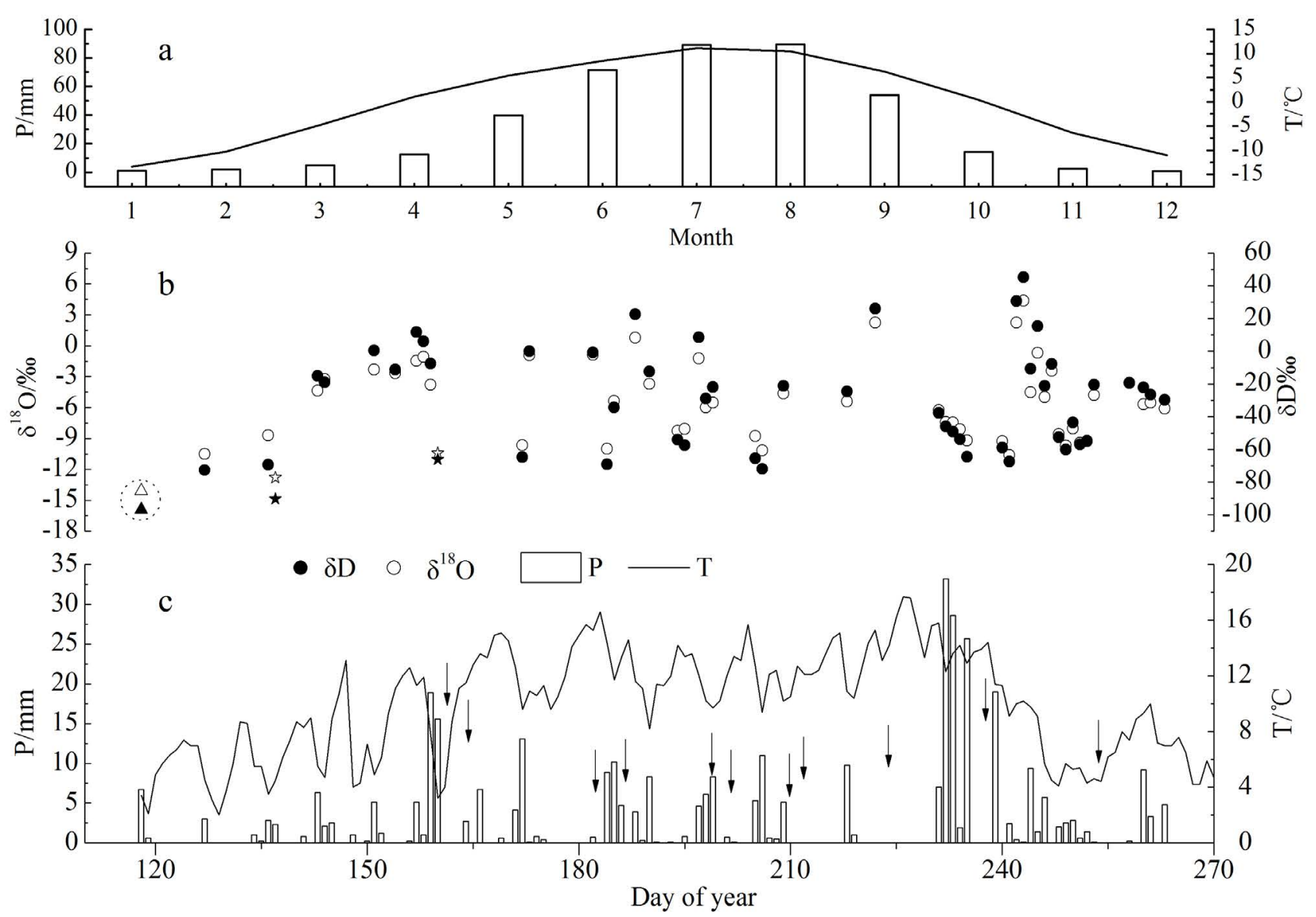

Figure 2: Average annual monthly air temperature $\left(T,{ }^{\circ} \mathrm{C}\right)$ and precipitation amount $(\mathrm{P}, \mathrm{mm}$, from 1958 to 2012) (a), temporal variations of isotopic contents in precipitation (b) and distribution of daily precipitation amount and air temperature (c) during April and September, 2013. Stars, dot circle and arrow represent rain plus snow, snow and sampling dates, respectively. 
ear model (Univariate analysis) with Tukey's test was used to examine the effects of experimental factors, including sampling date, depth on isotopic composition of soil water, and gravimetric soil water content. The significance level was 0.05 in all cases.

\section{Results}

\section{Variations in precipitation amount, tempera- ture, and isotopic composition of precipitation}

Air temperature and precipitation amount both showed a unimodal distribution, revealing high air temperature and large precipitation amounts (Figure 2a). During the study period, the air temperature varied from 2 to $17.7{ }^{\circ} \mathrm{C}$, and high temperatures was distributed in three growing months (June through August), the same time period during which precipitation was mainly concentrated, and the total precipitation amount from April through September was $357.9 \mathrm{~mm}$ (Figure 2c). 65\% of pre- cipitation occurred in small events $(<5 \mathrm{~mm}$ ), while five dry periods of more than eight consecutive days without any precipitation were found (Figure $2 b)$.

The isotopic compositions ( $\delta \mathrm{D}$ and $\delta^{18} \mathrm{O}$ ) of precipitation showed large variations during the study period $\left(\delta^{18} \mathrm{O}: 4.36\right.$ to $-14.1 \%$ with an average-weighted value of $-5.94 \%$, and $\delta D: 45.20$ to $-96.9 \%$ with an average-weighted value of $-34.7 \%$ o). Figure $2 b$ showed several heavy precipitation events in late August and solid water samples (snow and snow plus rain) had negative values, which was associated with effects of higher precipitation amount and reduced kinetic fractionation effects in solid water samples [26]. In addition, small precipitation events with relatively positive isotopic values were observed in Figure $2 b$, which may result from strong kinetic fractionation effect on these small events [26].

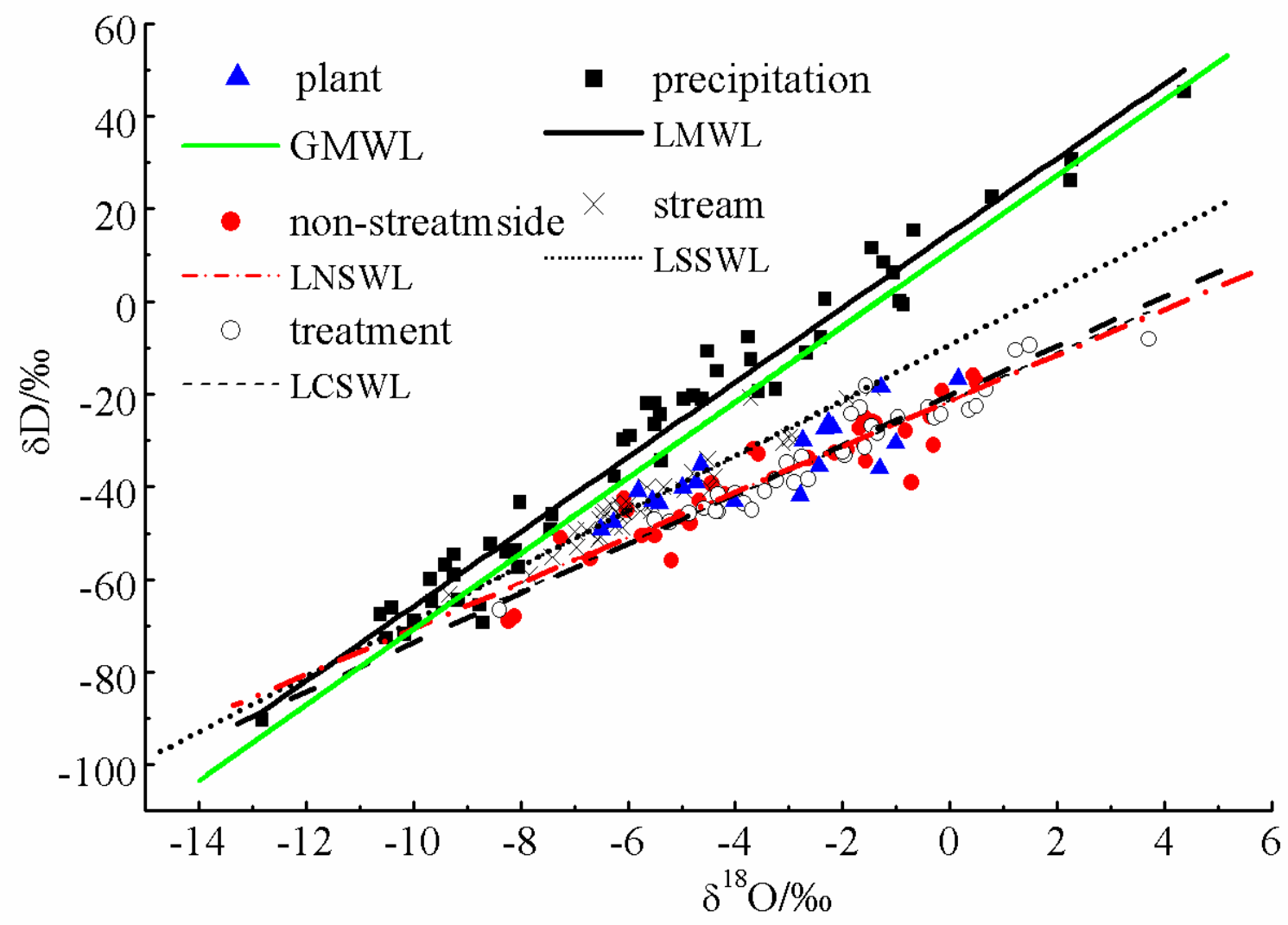

Figure 3: Relationship of $\delta D$ and $\delta^{18} \mathrm{O}$ in plant tissues (blue triangle), soil water and precipitation in Lake Qinghai Basin during the growing seasons. The GMWL (Global Meteoric Water Line, green line) with $\delta D=(8.2$ $\pm 0.07) \delta^{18} \mathrm{O}+(11.27 \pm 0.65)\left(r^{2}=0.98, n=203\right)$ is plotted for reference [30]. LMWL, LSSWL, LCSWL and LNSWL represent the linear fits in the precipitation (black square with solid line), soil water at the streamside (cross with black dot line), treatment (open circle with black dash line) and non-streamside (closed red solid circle with red dash dot line), respectively. 

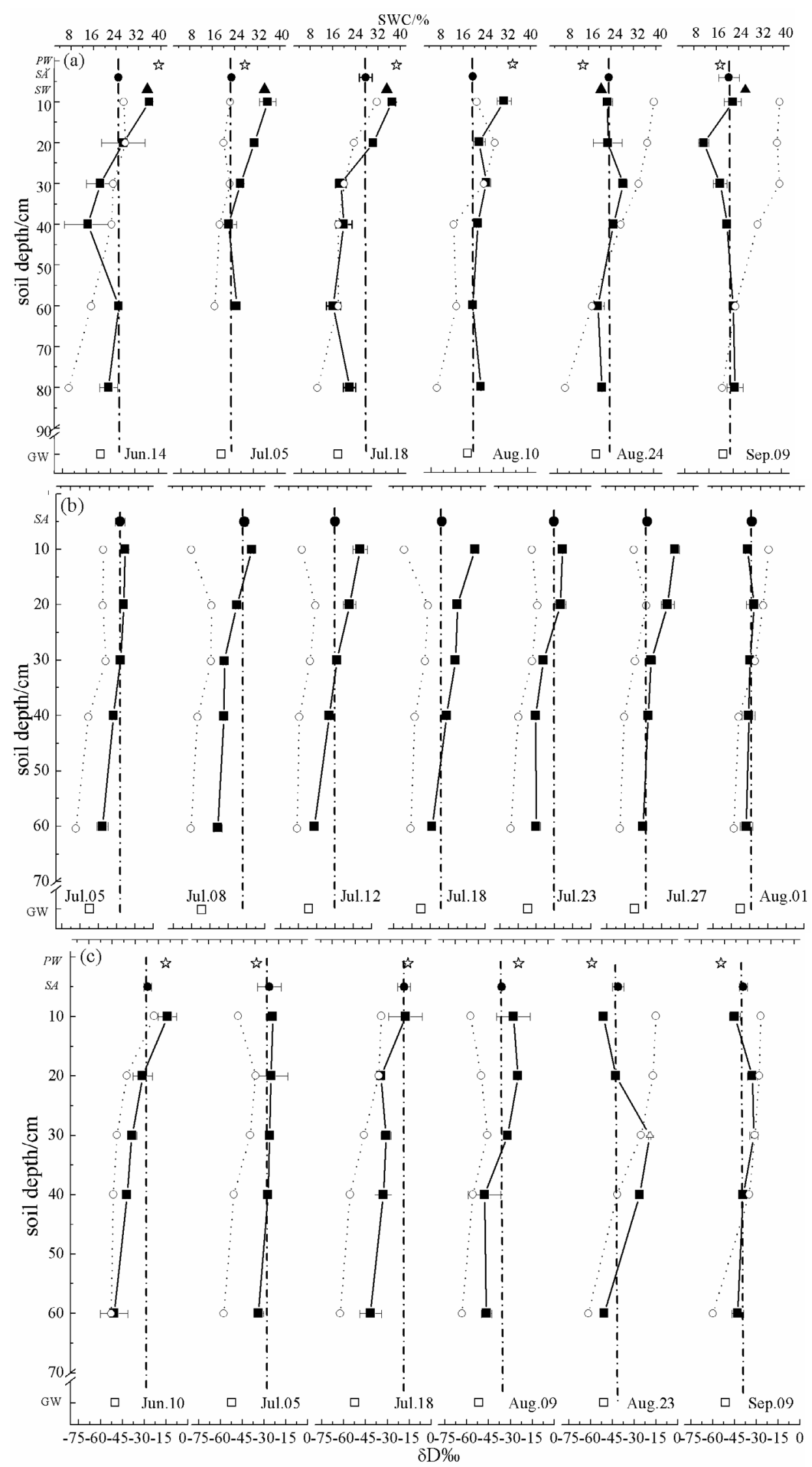

Figure 4: Temporal variations of soil water content (open circle) and $\delta D$ (closed square) in soil water, precipitation (PW with star), stream (SW with closed triangle), groundwater (GW with open square) and plant tissues of $A$. splendens (SA with closed circle) at the streamside (a), treatment (b) and non-streamside(c) during the growing seasons from June to September, 2013. Horizontal crossed bar represented \pm 1 standard error $(n=1-3)$. 
A strong correlation between $\delta D$ and $\delta^{18} \mathrm{O}$ was observed in precipitation, soil water, and plant tissue water during our study. A plot of $\delta \mathrm{D}$ versus $\delta^{18} \mathrm{O}$ values of precipitation formed a line with a slope of 8.07 and an intercept of 14.8 (Figure 3), which was refined as local meteoric water line (LMWL) for Lake Qinghai Basin. The slope and intercept of LMWL were close to the global meteoric water line (GMWL, 8.2 and 11.27). The relationships between $\delta D$ and $\delta^{18} O$ in soil water showed subtle differences between the three habitats. The slope and intercept of the aforementioned soil water and plant tissues water was lower than that of LMWL (Figure 3), as follows:

$\delta D=5.89 \delta^{18} O-9.94\left(n=36, r^{2}=0.992, p<0.001\right)$ at the streamside site (LSSWL);

$$
\delta D=5.14 \delta^{18} O-21.3\left(n=37, r^{2}=0.923, p<0.001\right)
$$
at the rainout treatment site (LCSWL);

$$
\delta D=4.88 \delta^{18} O-21.6\left(n=30, r^{2}=0.849, p<0.01\right)
$$
at the non-streamside site (LNSWL).

\section{Soil moisture and its isotopic contents across three habitats}

Figure 4 showed that soil water content (SWC) and isotopic value $(\delta D)$ in soil water exhibited distinct seasonal changes in different soil profiles across the three habitats, with the highest water content (most depleted values in $\delta \mathrm{D}$ ) at the streamside site and the lowest water content (most pos- itive values in $\delta D$ ) in the rainout treatment. SWC exhibited no clear seasonal changes in the 30-60 $\mathrm{cm}$ soil profile. The effect of rainout and irrigation on soil moisture was greater at the treatment site (Figure 4b). Soil moisture and $\delta D$ in $0-30 \mathrm{~cm}$ soil water showed greater variability than $30-60 \mathrm{~cm}$ soil water at all habitats. Sampling date and depth both significantly affected SWC and $\delta D$ regardless of habitat, with date $\times$ depth interaction also significantly affecting $\delta D$ at the rainout treatment site and SWC at both streamside and non-streamside sites (Table 1).

Table 1 displayed that soil water $\delta D$ values differed significantly among sampling dates and depths among the three habitats $(P<0.05)$. The $\delta \mathrm{D}$ values greatly varied at the $0-30 \mathrm{~cm}$ layer, while $\delta D$ values were less variable at $40-60 \mathrm{~cm}$, especially at the rainout treatment. Except for the variations in isotopic contents in the rainout treatment, the $\delta D$ of surface soil water was subject to recent inputs of isotopically depleted rainfall, resulting in lower isotopic concentrations. For instance, five consecutive rainy days from August 19 (DOY236) to August 23 (DOY256) totaling $119 \mathrm{~mm}$ of precipitation showed negatively average-weighted $\delta \mathrm{D}$ values $(-51.86 \%)$, with soil water $\delta D$ values at $10 \mathrm{~cm}$ more negative than those at other soil depths at streamside and non-streamside sites (Figure 2 and Figure 4).

\section{Isotopic composition of plant tissues in $A$.}

Table 1: Univariate analysis of the effects of date and soil depth on $\delta d$ and SWC (soil water content) in three

\begin{tabular}{|c|c|c|c|c|c|c|c|c|c|}
\hline \multirow{2}{*}{ Site } & \multicolumn{5}{|l|}{$\delta \mathrm{D} / \%$} & \multicolumn{4}{|c|}{ SWC/\% } \\
\hline & source & df & MS & $\mathbf{F}$ & Sig. & df & MS & $\mathbf{F}$ & Sig. \\
\hline \multirow{4}{*}{ Streamside } & Depth & 5 & 639.989 & 4.743 & 0.002 & 5 & 0.067 & 33.56 & 0 \\
\hline & Date & 5 & 881.556 & 6.533 & 0 & 5 & 0.028 & 14.291 & 0 \\
\hline & Depth $\times$ Date & 24 & 180.968 & 1.341 & 0.202 & 24 & 0.004 & 2.129 & 0.013 \\
\hline & Error & 40 & 134.945 & & & 49 & 0.002 & & \\
\hline \multirow{4}{*}{ Treatment } & Depth & 4 & 758.516 & 22.153 & 0 & 4 & 0.024 & 25.974 & 0 \\
\hline & Date & 6 & 655.247 & 19.137 & 0 & 6 & 0.006 & 6.407 & 0 \\
\hline & Depth $\times$ Date & 24 & 116.505 & 3.403 & 0.001 & 24 & 0.001 & 1.448 & 0.14 \\
\hline & Error & 34 & 34.241 & & & 45 & 0.001 & & \\
\hline \multirow{4}{*}{ Non-streamside } & Depth & 5 & 468.364 & 4.437 & 0.003 & 5 & 0.018 & 25.778 & 0 \\
\hline & Date & 4 & 213.574 & 1.023 & 0.014 & 4 & 0.044 & 62.545 & 0 \\
\hline & Depth $\times$ Date & 20 & 176.311 & 1.67 & 0.093 & 20 & 0.004 & 5.724 & 0 \\
\hline & Error & 33 & 105.558 & & & 45 & 0.001 & & \\
\hline
\end{tabular}
habitats.

MS: Mean Square; Significance level was 0.05. 


\section{splendens and inferred depth of water uptake}

Figure 4 showed variations of $\delta \mathrm{D}$ in $A$. splendens across three habitats, with plants growing in the streamside site having $\delta D$ values ranging from -35.18 to $-49.22 \%$ o with a mean value of $-43.15 \%$. The same measurements ranged from -18.5 to $-40.94 \%$ with a mean value of $-31.38 \%$ at the non-streamside site and from -16.77 to $-43.16 \%$ o with a mean $\delta D$ value of $-32.14 \%$ at the rainout treatment site. The isotopic contents of groundwater and stream water varied from $-49.92 \%$ to $-52.42 \%$ and from -22.06 to $-47.78 \%$, respectively. This trend likely reflects the rainfall history of this region, antecedent soil moisture, and differences among habitat conditions of these three sampling sites (See next discussion section). The more depleted plant tissue $\delta \mathrm{D}$ values suggest that A. splendens utilizes below $40 \mathrm{~cm}$ soil water with more isotopically depleted soil water at the rainout treatment site (Figure 4). In addition, plant tissue isotopic values closely matched those of upper 30 $\mathrm{cm}$ soil water on August 23 (DOY256) and Septem- ber 9 (DOY 252) at streamside and non-streamside sites, likely reflecting a plastic response of $A$. splendens to the recent rainfall.

Due to the influence of rainfall input at the streamside and non-streamside sites, isotopic data from plant tissues matched soil water isotopic values in the upper $20 \mathrm{~cm}$ and about $60 \mathrm{~cm}$ depth in June during early growth stages (Figure $4 \mathrm{a}$ and Figure 4c). As the upper $30 \mathrm{~cm}$ soil layer became wetter, water sources of $A$. splendens gradually shifted to utilize $0-30 \mathrm{~cm}$ soil water on Aug. 24 and Sep. 09 (Figure 4a). The isotopic differences between stream water and plant tissue water may suggest that $A$. splendens relied less on stream water than on groundwater during the growing season (Figure 4a). Without the effects of rainfall on $A$. splendens at the rainout treatment site, plant tissue $\delta D$ values were similar to $0-30 \mathrm{~cm}$ soil water on Jul. 5 (Figure 4b). However, as the soil progressively dried out, plant water uptake shifted to utilize below $40 \mathrm{~cm}$ soil layers, from the upper $20 \mathrm{~cm}$ to the below 40 $\mathrm{cm}$ during Jul. 5 and Jul. 18, respectively. Shallow

Table 2: Percentages of potential water sources (\%) for $A$. splendens growing at three habitats (streamside, rainout treatment and non-streamside) during the growing season.

\begin{tabular}{|c|c|c|c|c|c|c|c|c|}
\hline Site & Source ${ }^{*}$ & Jun.14 & Jul.05 & Jul.18 & Aug.10 & Aug.24 & Sep.09 & \\
\hline \multirow{6}{*}{ Streamside } & 10 & $19(0-49)$ & $1.6(0-7)$ & $30.7(0-54)$ & 0 & $19.5(0-93)$ & $21.3(0-86)$ & \\
\hline & 20 & $21.9(0-86)$ & $2.7(0-11)$ & $25.4(0-80)$ & $0.5(0-2)$ & $19.6(0-94)$ & $6.1(0-19)$ & \\
\hline & 30 & $13(0-63)$ & $6.3(0-24)$ & $10.6(0-51)$ & $0.1(0-1)$ & $13.5(0-42)$ & $12(0-40)$ & \\
\hline & 40 & $10.3(0-50)$ & $79.6(64-92)$ & $11.3(0-54)$ & $0.8(0-3)$ & $18.7(0-69)$ & $18.3(0-76)$ & \\
\hline & 60 & $20.2(0-99)$ & $9.7(0-36)$ & $9.2(0-45)$ & 98.2(97-99) & $13.3(0-57)$ & $21.3(0-85)$ & \\
\hline & 80 & $15.6(0-76)$ & & $12.8(0-62)$ & $0.4(0-2)$ & $15.4(0-68)$ & $21.1(0-81)$ & \\
\hline \multirow{6}{*}{ Treatment } & & Jul.05 & Jul.08 & Jul.12 & Jul.18 & Jul. 23 & Jul.27 & Aug.01 \\
\hline & 10 & $25.8(0-78)$ & $67.9(49-77)$ & $12.6(0-45)$ & $5.5(0-22)$ & $33.3(0-67)$ & $3(0-12)$ & $8.1(0-33)$ \\
\hline & 20 & $26.4(0-83)$ & $13(0-51)$ & $16.3(0-59)$ & $9.6(0-38)$ & $32.6(0-73)$ & $4(0-16)$ & $62.2(47-73)$ \\
\hline & 30 & $25.6(0-98)$ & $6.8(0-27)$ & $23.9(0-91)$ & $10.5(0-42)$ & $13.9(0-45)$ & $12.9(0-50)$ & $13.2(0-53)$ \\
\hline & 40 & $14.5(0-43)$ & $6.8(0-26)$ & $25.9(0-81)$ & $17(0-66)$ & $10.1(0-32)$ & $21.7(0-82)$ & $9.9(0-40)$ \\
\hline & 60 & $7.7(0-22)$ & $5.5(0-22)$ & $21.3(0-54)$ & 57.4(34-77) & $10.1(0-32)$ & $58.4(18-87)$ & $6.6(0-27)$ \\
\hline \multirow{6}{*}{$\begin{array}{l}\text { Non- } \\
\text { streamside }\end{array}$} & & Jun.10 & Jul.05 & Jul.18 & Aug.09 & Aug.24 & Sep.09 & \\
\hline & 10 & $45.1(21-63)$ & $22.4(0-77)$ & $94.2(93-96)$ & $19.6(0-59)$ & $23.2(0-68)$ & $20.3(0-55)$ & \\
\hline & 20 & $20(0-79)$ & $24.6(0-88)$ & $1.5(0-5)$ & $17.7(0-51)$ & $25.5(0-93)$ & $16.6(0-49)$ & \\
\hline & 30 & $13.8(0-55)$ & $25.3(0-99)$ & $1.9(0-7)$ & $22.5(0-74)$ & $12.6(0-31)$ & $15.5(0-45)$ & \\
\hline & 40 & $12.1(0-47)$ & $20.3(0-68)$ & $1.5(0-6)$ & $19.7(0-48)$ & $15.4(0-40)$ & $25.2(0-97)$ & \\
\hline & 60 & $9.1(0-36)$ & $7.4(0-23)$ & $0.8(0-4)$ & $20.5(0-51)$ & $23.4(0-69)$ & $22.4(0-65)$ & \\
\hline
\end{tabular}

*Average source percentage calculated from the Iso Source mixing model by Phillips, et al. [23] is showed following the range of minimum and maximum percentages (in parentheses). 
soil moisture increased sharply to $17.7 \%$ and $27.3 \%$ after two watering events on Jul. 21 and Jul. 31 (Figure $4 b)$.

Similar to the above direct analysis, Table 2 displayed that $A$. splendens utilized different proportions of soil water at different habitats during the growing season. A. splendens mainly depended on water (from $53.9 \%$ at the streamside site to $78.9 \%$ at the non-streamside site) from $0-30 \mathrm{~cm}$ soil water and absorbed a smaller proportion of water from $60 \mathrm{~cm}$ soil profile during the early growing seasons. The proportions of plant water uptake shifted in association with variations of soil moisture (Table 2 and Figure 4).

\section{Discussion}

\section{Variations of soil moisture and stable isotope in precipitation, soil water, and plant tissue}

Precipitation is the main source of water inputs for A. splendens steppe ecosystems in arid and semi-arid regions of the Lake Qinghai watershed. Precipitation isotopic concentrations exhibited significant variations during the sampling periods (Figure 2a), indicating that distinct moisture sources (e.g., summer monsoons vs. recycled water vapor from inland) resulted in different precipitation isotopic signatures in this watershed $[14,26,27]$. Meanwhile, soil water isotope compositions and soil moisture varied spatiotemporally at our study sites (Figure 4), in ways consistent with influences from both evaporative processes and precipitation events [28,29]. Water from heavy, long-lasting precipitation events infiltrated into $40-60 \mathrm{~cm}$ soil layers, resulting in more isotopically depleted soil water during late August and early September, increasing the homogeneity of isotopic contents in the soil column (Figure 4). Moreover, isotopic concentrations in plant tissue water of $A$. splendens had great seasonal variations across the three habitats (Figure 4), suggesting this species obtained water from various parts of the soil profile.

The LMWL established in Figure 3 was similar to the GMWL defined by Rozanski, et al. [30]. Deviations from GMWL are known to be controlled by local meteorological conditions such as wind speed, relative humidity, temperature, and evaporative fractionation $[27,30]$. In this study, the slope and intercept of the $\delta D-\delta^{18} O$ linear regression for soil water at three habitats greatly deviated from LMWL and GMWL, indicating that soil water had previously experienced strongly evaporative frac- tionation effects, such as equilibrium and kinetic fractionation [31]. In addition, the slope and intercept for the rainout treatment site (5.14 and -21.3, respectively) and non-streamside site (4.88 and -21.6, respectively) were lower than those for the streamside site (5.89 and -9.94, respectively), suggesting that evaporation was greater at the rainout treatment and non-streamside sites than that at the streamside site. Additionally, both $\delta \mathrm{D}$ and $\delta^{18} \mathrm{O}$ values of plant tissue water scatter along those of soil water, which suggest that plants mainly extracted water from various soil profiles $[32,33]$.

Although differences in soil moisture occurred across sampling dates and habitat sites, the general trend for SWC was similar. Soil moisture of $0-20 \mathrm{~cm}$ soil layers exhibited a large, fluctuating range that sensitively responded to rainfall recharge except at the rainout treatment site and evaporation effect (Figure 4). Precipitation input taken great effect on soil moisture of whole profile, e.g., long-lasting rain on September 9 (Figure 4a). Differences in evaporation among the three study sites were deduced from decreases in soil moisture (Figure 4). This may be related with differences in vegetation cover, which was higher at the streamside site than at the other two sites during the study period. These results were similar to those previously reported by Asbjornsen, et al. [22], who demonstrated that soil water from sites with different amounts of vegetation cover display distinct soil moisture and isotopic concentrations in soil profiles due to differential impacts by evaporative process.

\section{Plasticity of $\boldsymbol{A}$. splendens water-use uptake}

The plasticity of plant water uptake from different sources may have competitive advantages to thrive in arid and semi-arid environment, because it can allow the plant to exploit enough water to maintain growth in environments with more dynamic soil moisture conditions [28,34]. In this study, $A$. splendens displayed high plasticity in water uptake from soil profiles associated with seasonal water variations and when situated in different habitats conditions (Figure 4). This plasticity was closely related to root architecture, consistent with the results of [35], who found that the Stipa grandis also showed a flexible, resource-dependent water use strategy in response to changing availability of soil water.

Depth of soil water acquisition by plants is 
related to root density distribution and active root area [36,37]. As reported by Wang, et al. [17], root biomass of $A$. splendens mainly distributed in the upper $30 \mathrm{~cm}$ soil layer with densely surficial fibrous roots and root density sharply declining with increasing depth. The high density of fibrous roots near the soil surface may be beneficial for efficient absorption of soil water and nutrients [38]. In the present study, the surficial functional roots of $A$. splendens were activate and mainly acquired 0-20 $\mathrm{cm}$ soil water recharged by precipitation several days prior to our sampling, as demonstrated by soil and plant tissues water isotopic signatures (Figure 4a and Figure 4c). This allowed the plants to sustain leaf expansion and plant growth during seedling establishment in early June. In the early July, as the $0-30 \mathrm{~cm}$ soil moisture gradually became depleted by root extraction and evaporation, in turn decreasing soil water availability, the depth of water uptake shifted to $40-60 \mathrm{~cm}$ soil layers. However, the proportions of $A$. splendens uptake from $0-20 \mathrm{~cm}$ soil layers still markedly increased after long-lasting, heavy precipitation events in late August and early September (Table 2), indicating significant plasticity in $A$. splendens water uptake. This pattern is similar to that seen in species with functionally dimorphic roots, such as tree or shrub in arid and semi-arid environment such as Juniperus ashei, which exhibit clear seasonal shifts in water source in response to changes in soil water availability $[4,39,40]$. This plasticity of water uptake pattern among different soil layers appears to be of importance for species coexisting and growing in water-limited environments $[35,41]$. Thus, we suggest that soil water uptake patterns in $A$. splendens facilitate community survival and efficient use of soil water sources to reduce water stress during prolonged droughts.

Previous studies have identified changes in water use strategies in response to varied conditions of water resources via an isotopic inference approach [41,42]. However, when the isotopic gradient varies with an asymptotic and irregular pattern, such as in soil profiles receiving more isotopically depleted rainfall, artifacts of input water differentiation can produce misinterpretations of depth of water uptake, obscuring plant water use strategies in response to changes of water source. We observed the possibility of such results in $A$. splendens responses to rainfall (Figure $4 a$, Figure $4 c$ ). Such artefacts may be overcome by quantifying soil wa- ter content across soil layers, as isotopic inference assumes that plants absorb water from relatively high SWC [43]. Our results showed that A. splendens more strongly differed in water use strategies in response to moisture conditions at the rainout treatment site than at the other two habitat sites (Figure 4b). Soil water content drastically varied due to two watering events on Jul. 21 and Jul. 31; This in turn had a pronounced effect on the isotopic compositions of plant tissue water, suggesting that A. splendens utilizes more water from upper soil layers after watering events. These results are similar to those in previous studies [5,44], who found that plants shifted their main water sources from upper soil layers during the wet season to deeper layers during the dry season.

It is noteworthy that water uptake strategies of A. splendens greatly differed in different habitats, indicating that $A$. splendens can flexibly adapt the water uptake pattern dependence on water availability to survive. We conclude from our results that A. splendens located near streams do not rely on stream water as a main water source, but instead depends on soil water (Figure 4a). This is further supported by the fact that when the stream dried up on Aug. 10 due to prolonged drought (Figure 4a), A. splendens acquired high proportions of its tissue water (98.2\%) from $60 \mathrm{~cm}$ soil layers (Table 2). This pattern was likely observed in three mature tree species by Dawson, et al. [45] and in Eucalyptus camaldulensis by Thorburn, et al. [46], who suggested that streamside trees depend on more reliable water sources such as groundwater and soil water due to its lower vulnerability to changes in stream flow and water quality.

Our results from the direct inference approach also show that $A$. splendens does not obtain groundwater as a main water sources at the three habitats (Figure 4). These results are inconformity to previous study by Chen, et al. [12], who demonstrated that $A$. splendens is considered as a good indicator of groundwater for local herdsman. Drought conditions by rainfall exclusion during our study period may not have been extreme enough to cause significant competition for limited soil water resources and the need to utilize groundwater. Nonetheless, the maximum rooting depth of this species may extend more than $1.6 \mathrm{~m}$ at a location where the groundwater table was no less than 2.5 $\mathrm{m}$ (survey from a backhoe excavated trench at our 
study site, 2013). We deduce that groundwater may still be utilized by $A$. splendens via capillary rise or condensation water in deeper soil layers. This possibility should be further tested by rainout treatments or deuterium enriched irrigation, which would help improve our understanding of inter- and intra-specific competition for available soil water sources and of the regional hydrological balance for the Lake Qinghai watershed.

Plasticity of this species' use of distinct water sources is strategically advantageous to their growth and survival, because the growth of $A$. splendens community occurs mainly during the rainy period. However, source-water acquisition flexibly switch from different soil profiles was typical in the drought conditions (i.e., rainfall exclusion in this study). The observation of this water-uptake pattern and associated morphology of $A$. splendens represent the potential for new knowledge about water sources in the Lake Qinghai watershed. We can deduce that if future soil water availability becomes more unpredictable, it will be conducive to the survival of $A$. splendens community because of its root plasticity under current climate warming. Knowledge of water uptake in this species will also provide important implications for vegetation restoration in $A$. splendens steppe communities occurring in the recently degraded region of the Lake Qinghai Basin.

\section{Conclusions}

Based on direct inference and multiple isotope mixing models, $A$. splendens water uptake showed a high degree of plasticity in water uptake pattern, in association with soil water availability at three habitat conditions. As $0-30 \mathrm{~cm}$ soil moisture was gradually depleted, plant use of water from 0-30 $\mathrm{cm}$ soil layers decreased and shifted to the 40-60 $\mathrm{cm}$ soil layers. $A$. splendens heavily depended on $0-20 \mathrm{~cm}$ soil water at the streamside site $(40.9 \%)$ and the non-streamside site (65.1\%) during the early growing periods when plant leaves and roots began to extend. Nonetheless, the proportion of water uptake from $0-30 \mathrm{~cm}$ soil layers increased markedly after long-lasting, heavy precipitation events in late August and early September. Water utilization pattern of $A$. splendens was similar to that previously observed in some efficient plasticity of water use species, indicating that $A$. splendens efficiently utilized the limited soil water sources to become the dominant species in the warm temper- ate steppes of Lake Qinghai. Our results showed the effect of plasticity dependence on soil water source was typical in the drought conditions. The plasticity of water uptake for $A$. splendens had stronger competitive advantage for limited water source and nutrients.

\section{Acknowledgement}

The study was financially supported by the $\mathrm{Na}$ tional Science Foundation of China (NSFC 41130640, 41025001 and 41321001), and the New Century of Excellent Talents Funds (JXDZ-YXRC20171).

\section{References}

1. Easterling DR, Meehl GA, Parmesan C, Changnon SA, Karl TR, et al. (2000) Climate extremes: Observations, modeling, and impacts. Science 289: 2068-2074.

2. Weltzin JF, Loik ME, Schwinning S, Williams DG, Fay PA, et al. (2003) Assessing the response of terrestrial ecosystems to potential changes in precipitation. Bioscience 53: 941-952.

3. Gregory JM, Mitchell J, Brady A (1997) Summer drought in northern Midlatitudes in a time-dependent $\mathrm{CO} 2$ climate experiment. Journal of Climate 10 : 662-686.

4. McCole AA, Stern LA (2007) Seasonal water use patterns of Juniperus ashei on the Edwards Plateau, Texas, based on stable isotopes in water. Journal of Hydrology 342: 238-248.

5. Eggemeyer KD, Awada T, Harvey FE, Wedin DA, Zhou $X$, et al. (2009) Seasonal changes in depth of water uptake for encroaching trees Juniperus virginiana and Pinus ponderosa and two dominant $\mathrm{C} 4$ grasses in a semiarid grassland. Tree Physiology 29: 157-169.

6. Dai Y, Zheng X-J, Tang L-S, Li Y (2015) Stable oxygen isotopes reveal distinct water use patterns of two Haloxylon species in the Gurbantonggut Desert. Plant Soil 389: 73-87.

7. Liu W, Wang P, Li J, Liu W, Li H (2014) Plasticity of source-water acquisition in epiphytic, transitional and terrestrial growth phases of Ficus tinctoria. Ecohydrology 7: 1524-1533.

8. Estrada-Medina H, Santiago L, Graham R, Allen M, Jimenez-Osornio J (2013) Source water, phenology and growth of two tropical dry forest tree species growing on shallow karst soils. Trees 27: 1297-1307.

9. Ryel R, Ivans C, Peek M, Leffler AJ (2008) Functional differences in soil water pools: A new perspective on plant water use in water-limited ecosystems. In: Luttge U, Beyschlag W, Murata J, Progress in Botany. Springer Berlin Heidelberg, 397-422. 
10.Good SP, Noone D, Bowen G (2015) Hydrologic connectivity constrains partitioning of global terrestrial water fluxes. Science 349: 175-177.

11.Schlesinger WH, Reynolds J, Cunningham GL, Huenneke L, Jarrell W, et al. (1990) Biological feedbacks in global desertification. Science 247: 1043-1048.

12.Chen G, Peng M (1993) Community characteristics and distribution laws of Achnatherum splendens in Qinghai Province. Acta Botanica Boreali-Occidentalia Sinica 13: 154-162.

13. Huai H, Wei W, Zhang Y (2008) Characteristics of the Achnatherum splendens community along the Qinghai-Tibet Railway, China. Frontiers of Biology in China 3: 477-483.

14.An Z, Colman SM, Zhou W, Li X, Brown ET, et al. (2012) Interplay between the Westerlies and Asian monsoon recorded in Lake Qinghai sediments since 32 ka. Scientific Reports 2: 619.

15.Zhu B, Chen X, Zheng Y, Li Y (2009) Correlation analysis between small-scale surface runoff and precipitation of the grassland near the north shore of Qinghai Lake. Journal of Glaciology and Geocryology, 31: 1074-1079.

16. Barnard RL, de Bello F, Gilgen AK, Buchmann N (2006) The $\delta 180$ of root crown water best reflects source water $\delta 180$ in different types of herbaceous species. Rapid communications in mass spectrometry 20 : 3799-3802.

17.Wang J, Liu M, Sheng S, Xu C, Liu X, et al. (2008) Spatial distributions of soil water, salts and roots in an arid arbor-herb community. Acta Ecologica Sinica 28: 4120-4127.

18.West AG, Patrickson SJ, Ehleringer JR (2006) Water extraction times for plant and soil materials used in stable isotope analysis. Rapid Communications in Mass Spectrometry 20: 1317-1321.

19.Wu Y, Zhou H, Zheng XJ, Li Y, Tang LS (2013) Seasonal changes in the water use strategies of three cooccurring desert shrubs. Hydrological Processes.

20.West AG, Goldsmith GR, Brooks PD, Dawson TE (2010) Discrepancies between isotope ratio infrared spectroscopy and isotope ratio mass spectrometry for the stable isotope analysis of plant and soil waters. Rapid Communications in Mass Spectrometry 24: 1948-1954.

21. Wu Y, Zhou H, Zheng XJ, Li Y, Tang LS (2014) Seasonal changes in the water use strategies of three cooccurring desert shrubs. Hydrological Processes 28: 6265-6275.
22.Asbjornsen H, Shepherd G, Helmers M, Mora G (2008) Seasonal patterns in depth of water uptake under contrasting annual and perennial systems in the Corn Belt Region of the Midwestern US. Plant Soil 308: 69-92.

23.Phillips DL, Gregg JW (2003) Source partitioning using stable isotopes: Coping with too many sources. Oecologia 136: 261-269.

24.Phillips DL, Newsome SD, Gregg JW (2005) Combining sources in stable isotope mixing models: Alternative methods. Oecologia 144: 520-527.

25. Wang P, Song X, Han D, Zhang Y, Liu X (2010) A study of root water uptake of crops indicated by hydrogen and oxygen stable isotopes: A case in Shanxi Province, China. Agricultural Water Management 97: 475-482.

26.Dansgaard W (1964) Stable isotopes in precipitation. Tellus 16: 436-468.

27.Araguás-Araguás L, Froehlich K, Rozanski K (1998) Stable isotope composition of precipitation over southeast Asia. Journal of Geophysical Research 103: 721-728.

28. Ehleringer J, Dawson T (1992) Water uptake by plants: Perspectives from stable isotope composition. Plant Cell Environ 15: 1073-1082.

29.Gazis C, Feng X (2004) A stable isotope study of soil water: Evidence for mixing and preferential flow paths. Geoderma 119: 97-111.

30.Rozanski K, Araguas-Araguas L, Gonfiantini R (1993) Isotopic patterns in modern global precipitation. Climate Change in Continental Isotope Records 78: 1-36.

31. Barnes C, Allison G (1988) Tracing of water movement in the unsaturated zone using stable isotopes of hydrogen and oxygen. Journal of Hydrology 100: 143-176.

32.Weltzin JF, McPherson GR (1997) Spatial and temporal soil moisture resource partitioning by trees and grasses in a temperate savanna, Arizona, USA. Oecologia 112: 156-164.

33. Rossatto DR, da Silveira Lobo Sternberg L, Franco AC (2013) The partitioning of water uptake between growth forms in a Neotropical savanna: Do herbs exploit a third water source niche? Plant Biology 15: 84-92.

34.Leffler AJ, Caldwell MM (2005) Shifts in depth of water extraction and photosynthetic capacity inferred from stable isotope proxies across an ecotone of Juniperus osteosperma (Utah juniper) and Artemisia tridentata (big sagebrush). Journal of Ecology 93: 783-793. 
35. Yang H, Auerswald K, Bai Y, Han X (2011) Complementarity in water sources among dominant species in typical steppe ecosystems of Inner Mongolia, China. Plant Soil 340: 303-313.

36.Dawson TE, Pate JS (1996) Seasonal water uptake and movement in root systems of Australian phraeatophytic plants of dimorphic root morphology: A stable isotope investigation. Oecologia 107: 13-20.

37. Ogle K, Wolpert RL, Reynolds JF (2004) Reconstructing plant root area and water uptake profiles. Ecology 85: 1967-1978.

38.Sternberg LdS, Bucci S, Franco A, Goldstein G, Hoffman WA, et al. (2005) Long range lateral root activity by neo-tropical savanna trees. Plant Soil 270 : 169-178.

39.Singer MB, Stella JC, Dufour S, Piégay H, Wilson RJS, et al. (2012) Contrasting water-uptake and growth responses to drought in co-occurring riparian tree species. Ecohydrology 6: 402-412.

40.Schwendenmann L, Pendall E, Sanchez-Bragado R, Kunert N, Hölscher D (2014) Tree water uptake in a tropical plantation varying in tree diversity: Interspecific differences, seasonal shifts and complementarity. Ecohydrology 8: 1-12.
41. Meinzer FC, Andrade JL, Goldstein G, Holbrook NM, Cavelier J, et al. (1999) Partitioning of soil water among canopy trees in a seasonally dry tropical forest. Oecologia 121: 293-301.

42.Chimner RA, Cooper DJ (2004) Using stable oxygen isotopes to quantify the water source used for transpiration by native shrubs in the San Luis Valley, Colorado USA. Plant Soil 260: 225-236.

43.Li S, Tsujimura M, Sugimoto A, Sasaki L, Yamanaka $\mathrm{T}$, et al. (2006) Seasonal variation in oxygen isotope composition of waters for a montane larch forest in Mongolia. Trees 20: 122-130.

44.Ewe SM, Sternberg LL (2002) Seasonal water-use by the invasive exotic, Schinus terebinthifolius, in native and disturbed communities. Oecologia 133: 441-448.

45.Dawson TE, Ehleringer JR (1991) Streamside trees that do not use stream water evidence from hydrogen isotope ratios. Nature 350: 335-337.

46. Thorburn PJ, Walker GR (1994) Variations in stream water uptake by Eucalyptus camaldulensis with differing access to stream water. Oecologia 100: 293301. 